\title{
歯由来骬形成因子に閲する実駼的研究
}

\author{
千葉雅俊
}

\section{Experimental studies of bone morphogenetic protein derived from bovine tooth}

\author{
Masatoshi CHIBA
}

\begin{abstract}
A bone morphogenetic protein (BMP) that induces differentiation of mesenchymaltype cell into cartilage and bone was partially purified from bovine tooth. In this study, the activity of BMP was assayed by its ability to induce enchondral ossification after injections of samples into rat thigh muscles.

Frozen teeth were ground to fine particles and demineralized in $0.6 \mathrm{~N} \mathrm{HCl}$. The demineralized tooth matrix was treated with $4 \mathrm{M}$ guanidine hydrochloride to extract BMP. Three volumes of cold ethanol were added to the supernatant obtained by filtration and the insoluble materials formed were collected by centrifugation. These materials were redissolved in $4 \mathrm{M}$ guanidine hydrochloride and subjected to gel filtration using a Superose 12 column. The precipitate formed by adding three volumes of cold ethanol to each fraction was collected by centrifugation and BMP activity was assayed.

The molecular weight of BMP of bovine tooth analyzed by electrophoresis on a SDS polyacrylamide gel was 27,000 . The combination of partially purified BMP with $0.5 \%$ atelocollagen (in $\mathrm{HCl}, \mathrm{pH} \mathrm{3}$ ) more effectively enlarged the volumes of cartilage and bone than did BMPalone, indicating usefulness of atelocollagen as a carrier. BMP induced enchondral ossification in the periosteum of the femur as well as in the muscle, suggesting that the periosteum includes cells that differentiate into osteoblasts in response to BMP.
\end{abstract}

Key words: Bone morphogenetic protein, atelocollagen, enchondral ossification

緒言

従来骨代謝は，骨芽細胞や破骨細胞の活性を調節する 副甲状腺ホルモン, 活性型ビタミンDなどのホルモンを 中心に研究が進められてきた。最近, 骨や軟骨に存在し, 産生された局所で作用して骨代謝を制御していると考え られる様々な局所因子が報告されている1 （特に骨に 存在して未分化間葉系細胞に作用し, 軟骨内骨化を経て 骨組織を誘導する物質は，骨形成因子 (Bone morpho-

東北大学齿学部口腔外科学第 2 绕座

（主任：手島貞一帴授）

Second Department of Oral Surgery, Tohoku University School of Dentistry (Chief: Prof. Teiichi Teshima)

受付日：昭和63年 3 月 10 日 genetic protein 以下 BMP と略す）と命名され4，多く の研究者の注目を集めてきた。 BMP は骨組織以外にも ある種の骨肉腫細胞や象牙質にも存在していることが知 られており,これら BMP の精製が進んた結果，骨の BMP は分子量 $18,500 \pm 500$ の蛋白質(5), Dunn 骨肉腫の BMP は, 分子量 22,000 の塩基性眯水性蛋白質 ${ }^{6)}$, 象牙 質の BMP は分子量27,000の蛋白質である゙とされてい る.このような BMP の生化学的な研究をはじめとし,こ れまで BMP を自家骨に代わりらる移植材料として用い ることを目的とした研究 ${ }^{8,9)}$, BMP の周囲への抬散を防 いで目的とする部位に留めておくような delivery system としての担体の研究などが行われてきた10,11).

BMP の活性は異所性の骨形成を観察することによっ て行われてきたため，骨そのものに対する作用について はまた解明されていない点が多い、本研究は脱戻骨基質 に比へ強い骨誘導能があるとされる脱灰歯基質 ${ }^{12)} よ り$ 
BMP の精製を武み，BMP の佣組䄉に対する反応之 BMP の際床纫用を想定した场合のアテロコラーダンの 担体としての有用性について枱阷することを目的とし た.

\section{材料 と方 法}

\section{BMP の精紫}

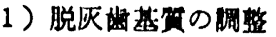

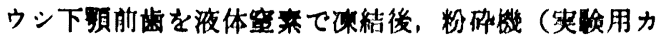
ッテインクミル Fritsch 社製) で約 $5 \mathrm{~mm}$ 以下に粉础し た．以下の処理は特にことわりのないかきりナべて,

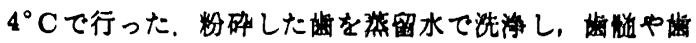
根膜を可及的に除去し，クロロホルム・メタノール（容 穔比 $1: 1$ )で1 時間脱脂後， $0.6 \mathrm{~N}$ の㙁酸で 24 時间 ス ターラーで港搂しなからら脱灰を行った。脱灰液は8 時间 每に交換した。 この脱灭歯を蒸留水で洗浄後，8 M塩化 リチウムで24時間処理した，次に蒸留水で十分洗浄し，

涑結乾燥しここれを脱灰歯基質とした（图1）。

また，象牙質に BMP が存在することを証明するた め, 齿をそのまま脱灰した後，歯頸部で切断し，歯冠部 に対して同様の処理を行いこれを脱灰冟冠部基筫とし た.

\section{2) BMP 画分の抽出}

脱灭歯基質をプロテアーセ阻害郕 $1 \mathrm{mM}$ ペンジルスル ホニルフルオライドを含む 6 倍量 (vol/wt) の $4 \mathrm{M}$ 塩酸 クフニジンでスターラーで筧拌しながら24時間抽出を行 い,ガーゼ, 濾紙 (No. 1 東洋满紙株式会社製)，ガラ スフィルター（GC 90 東洋润紙侏式会社製), メンブラ ンフィルター $(0.45 \mu \mathrm{m}$ フドンンテック東洋株式会社 製）の順に減圧滤過し，最後に隇菌フィルターニニット (0.2 $\mu \mathrm{m}$ Nalge 社製)で隇菌滤過し，濾液を塩酸グ ニシン抽出画分（以下 G-Ext）とした。この G-Ext に 3 倍量の $100 \%$ エタノール $\left(-20^{\circ} \mathrm{C}\right)$ を加えて 3 時間放 置した後， $3,000 \mathrm{G}$ で 5 分間遠心し, 沈測物を回収し, これをエタノール不溶性画分 (以下 Et-ppt) とした。 た上清を透析チューブ (SPECTRAPOR MW cut off 6, 000 8,000 SPECTRUM MEDICAL 社製)を用い て, 蒸留水に対して24時間透析を行った，透析後 3,000 Gで5 分間遠心し沈没物を回収し，これをェタノール可 溶性画分（以下 Et-sup）とした。

脱灰歯冠部基質についても同様の処理を行い,そのエ タノール不溶性画分を crown-Et-ppt とした.

3）ゲルクロマトグラフィーによる BMP の精製

Et-ppt $4 \mathrm{M}$ 塩酸クフニシンに溶解し，同じ溶液 で平衡化した高性能ゲルクロマトクラフィーカラム Superose 12 (HR 10/30 Pharmacia 社製) により分画 した. 溶出液は流速を $0.5 \mathrm{ml} / \mathrm{min}$ とし， $280 \mathrm{~nm}$ で吸 光度を測定し, $0.625 \mathrm{~m} l$ ずつ分取した。標準試料蛋白

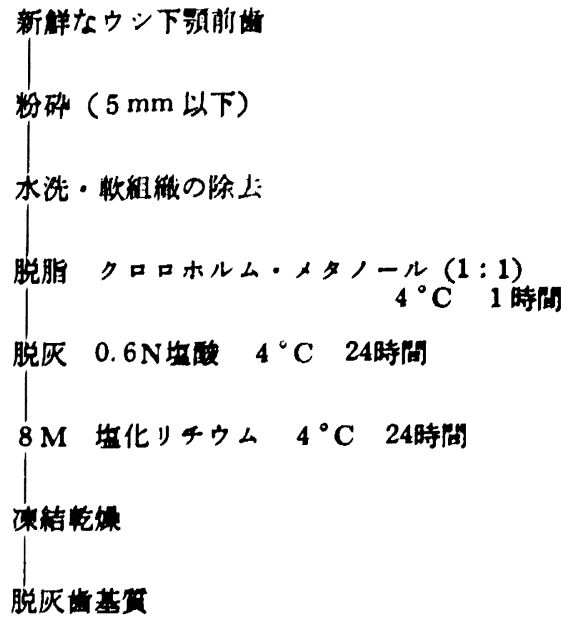

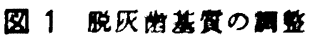

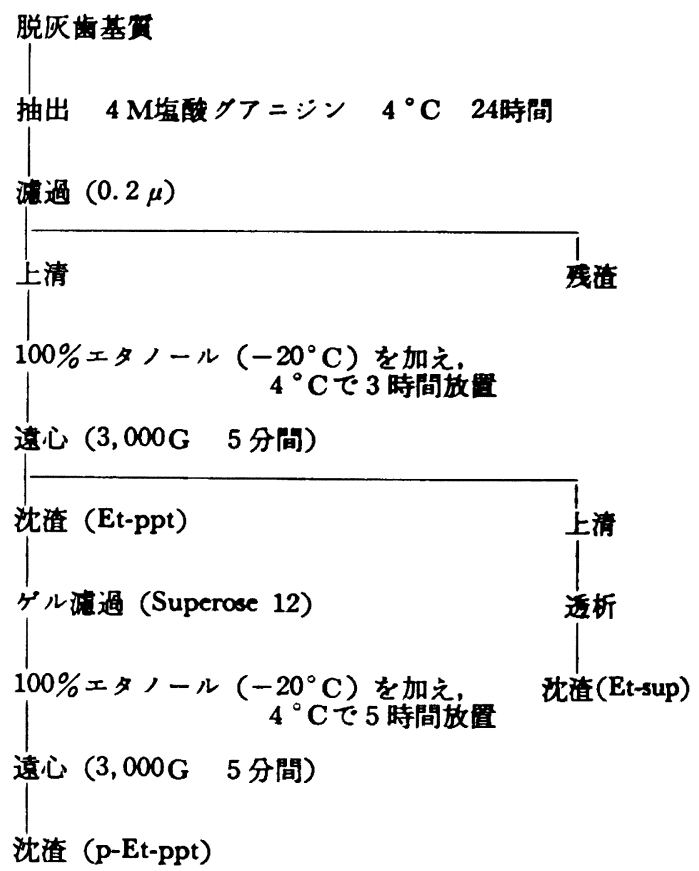

因 2 BMP の苚㟬

質として Pharmacia 社䌘の 分子量测定用キット（低分 子量領域用）を用いた，分画した各管出波を 6 つの画 分に分け，各画分に対して 3 倍量の $100 \%$ エタノール $\left(-20^{\circ} \mathrm{C}\right)$ を加えた． 5 時間後，それぞれの画分につい て 3,000G で5 分間遠心して沈没物を回收し，これを精 製エタノール不溶性画分 (以下 p-Et-ppt: Fr. I 〜 VI) とした（图2）。

以上の操作で得られた各画分をそれぞれ脱イオンホて 

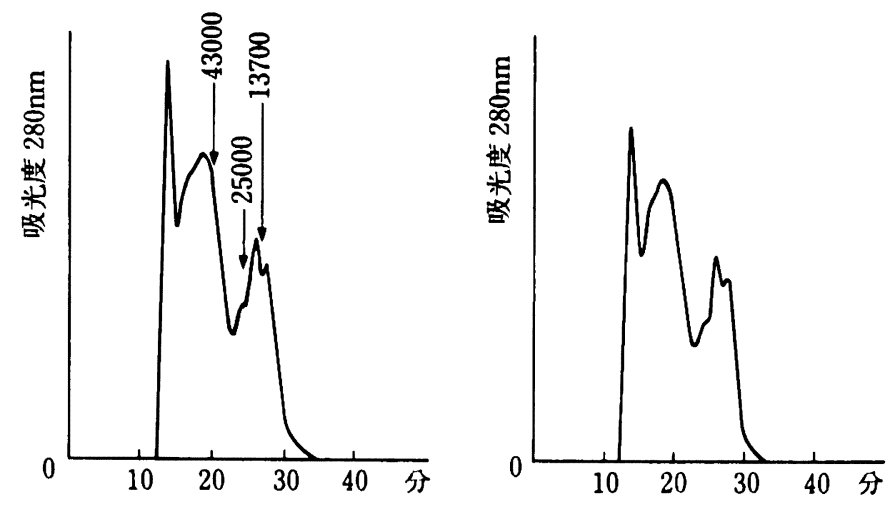

1

2

国 3

1. Et-ppt の Superose 12 にる分析桔果

2. crown-Et-ppt の Superose 12 にるる分析結果

洗浄し，凍結乾燥した。

4) SDS ポリアクリルアミドゲル電気泳動

p-Et-ppt について Laemmli'13) の方法に湡してて SDS ポリアクリルフミドゲル龟気泳動を行った，ゲルはゲル 濃度勾配が10〜20\%の電気泳動用グラジェントゲル（第 一化学薬品株式会社製) を用い, 電気泳動用綬衙液は,

$0.1 \%$ SDS/0.025 M Tris-HCl/0.192 M Glycine pH 8.4 を用いた。試料は $0.001 \% \mathrm{BPB} / 1 \% \mathrm{SDS} / 25 \%$ Glycerol/0.0625 M Tris- $\mathrm{HCl}$ pH 6.8 中で $100^{\circ} \mathrm{C} て ゙ 2$ 分間加熱して变性させた. $60 \mathrm{~mA} て ゙ 1$ 時間 20 分泳動を 行った. ゲルは, 電気泳動用銀染色試薬第一（第一化学 薬品株式会社製）を用いて銀染色を行った，分子量測定 のための標準蛋白質として，Bio-Rad 社製の電気泳動用 漂準蛋白質（低分子量領域用）を用いた。

\section{BMP 活性の検定方法}

仔ウシ真皮不溶性コラーゲンをペプシンで可溶化し精 製した $0.5 \%$ 酸性アテロコラーゲン溶液（pH 3 高研社 製）と各画分を十分混合した。混合した割合は, Et-ppt, crown-Et-ppt, Et-sup 各 $15 \mathrm{mg}$ にアテロコラーゲン 2 $\mathrm{ml}$, および p-Et-ppt $0.5 \mathrm{mg}$ と $5 \mathrm{mg}$ にアテロコラー ゲン $1.5 \mathrm{ml}$ とした. 各画分は酸性アテロュラーゲン溶 夜と混合した後,ラットに注入するまで $4^{\circ} \mathrm{C} て ゙$ 保存した. Et-ppt/アテロュラーゲンは, $4^{\circ} \mathrm{C}$ で完全にゲル化して おり, 注入直前に $40^{\circ} \mathrm{C} に$ 加温し一部ソル化させてから 注入した. コントロールとして，アテロコラーゲン単独 $(2 \mathrm{ml})$ および Et-ppt $15 \mathrm{mg}$ に生理食塩水 $2 \mathrm{ml}$ を注 入直前に混合したるのを用いた。

塩酸ケタミン麻酔下で，4週跲の雄 Wistar 系ラット の大腿骨に近接した筋肉内に，24ゲージの注射針を用い て各画分を注入した。 また Et-ppt/フテロコラーゲンは
表 1 精製エタノール不溶性画分

\begin{tabular}{l|l|c}
\hline p-Et-ppt & 各画分が溶出される時間 & $\begin{array}{l}\text { 骨酸学能の } \\
\text { 有無 }\end{array}$ \\
\hline Fraction. I & $12.5 \sim 15$ 分 & - \\
Fraction. II & $15 \sim 17.5$ 分 & - \\
Fraction. III & $17.5 \sim 22.5$ 分 & - \\
Fraction. IV & $22.5 \sim 25$ 分 & - \\
Fraction. V & $25 \sim 27.5$ 分 & + \\
Fraction. VI & $27.5 \sim 30$ 分 & - \\
\hline
\end{tabular}

試料 (Et-ppt) を注入してから上記の時間に溶出さ れる溶出液を集めて 6 つの画分に分けた。

ラット頭頂部骨膜下にも注入した。注入 2 週後に屠殺 し，大腿部と頭頂部をそれぞれ一塊として摘出し，10\% 中性緩衝ホルマリンで固定し, Plank•Rychlo 法14)で脱 灰した，大腿部は大腿骨骨幹中央部で横断面が出るよう に，頭頂部は頭頂骨前額断面が出るように標本を調整し た. 標本を通法どおりバラフィンに包埋し，4 $4 \mathrm{~m}$ の切 片を作成し，ヘマトキシリン・エオジン染色およびトル イシンブルー染色を施し，組織学的に観察した。

\section{結果}

\section{BMP の精製}

1) $\mathrm{BMP}$ 画分の抽出

ウシ下顠前歯を $0.6 \mathrm{~N}$ 塩酸で脱灰し，8 $\mathrm{M}$ 塩化りチウ ムで処理し, 倲結乾燥することにより, 䄪 $8 \%$ (dry wt) wet $w t$ ）の脱灰歯基質を得た。この脱灰雪基質を $4 \mathrm{M}$ 塩 


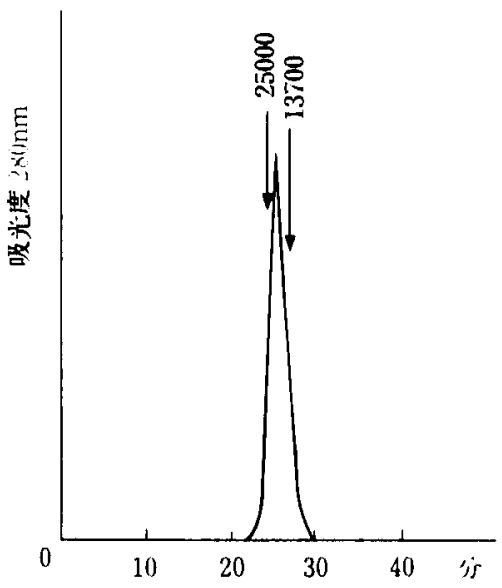

图 4 活性の别められた Fr. V の Superose 12 に上万分析結果

$97.4 \mathrm{~K}$

$66.2 \mathrm{~K}$

$42.7 \mathrm{~K}$

$31 \mathrm{~K}$

$21.5 \mathrm{~K}$

$14.4 \mathrm{~K}$
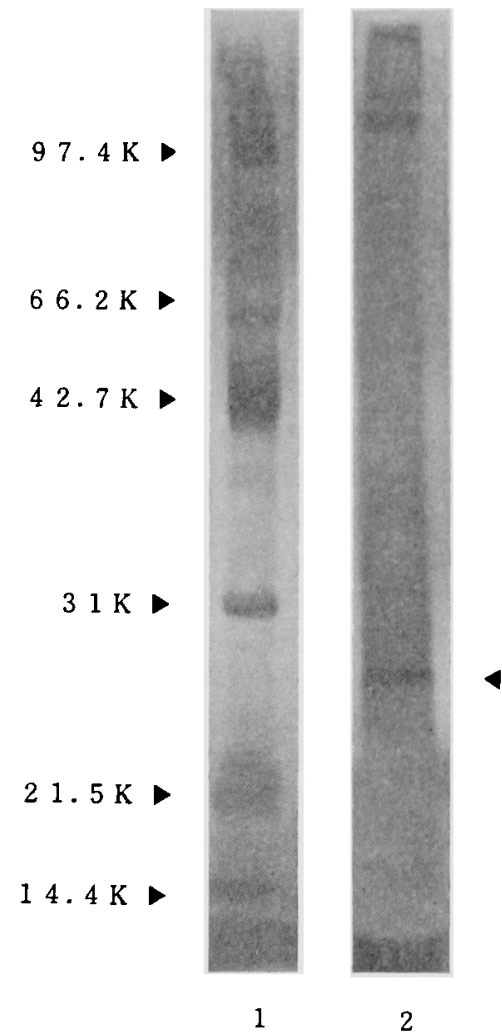

写真 1 SDS ボリフクリルアミドゲル䉓気泳動像
1. 分子量マ一カー
2. Fr. V

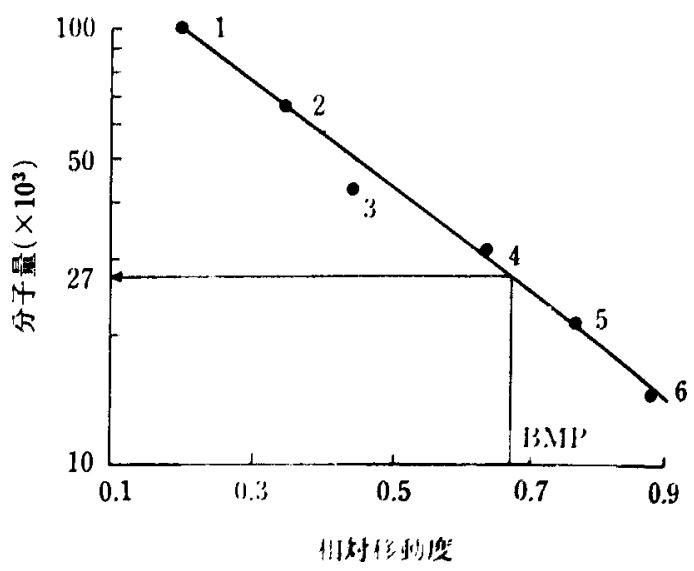

1. Rabbit muscle phosphorylase b 97,400

2. Bovine serum albumin 66,200

3. Hen egg white ovalbumin 12,699

4. Bovine carbonic anhydrase 31,000

5 . Soybean trypsin inhibitor 21,500

6 . Hen egg white lysozyme 14,400

因 5 BMP の分子昷の推定

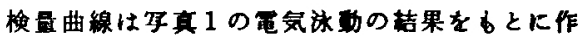
成した。

酸グアニジンで24 時間抽出し，その抽出画分 (G-Ext) に100\%×タノールを加えてェタノール不溶性画分 (Etppt）とェタノール可溶性画分 (Et-sup) に分崔した。 Et-ppt は，脱灰基質の約 $1.7 \%$ (dry wt/wt) であっ た.

2) BMP の精製

Et-ppt, crown-Et-ppt についてて Superose 12 を用い てゲルクロマトクラフィーを行い，因3１，2に示すよ らにはとんど同じ容出バターンを得た。表 2 で示すよう に骨諉導は Et-sup には認められず Et-ppt にその活性 が認められたので Et-ppt について更に棈製を進めた。

Et-ppt を表 1 のように Superose 12 を用いて6つの画 分に分けた，6つの画分の5ち分子量 25,000 以上の国分 (Fr. I〜N) はェタノールを加えるとただちに沈晸 を生じたのに対して，分子量25,000以下の画分 (Fr. V, VI）は3時間経過してもかずかな沈没物しか生じなかっ

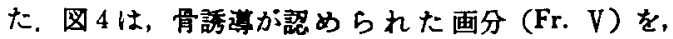
Superose 12を用いて Et-ppt と同じ条件で分析した結果 を示したものである．分子量13,700～25,000の間にピー クを持つ溶出バタンが得られた。 また，SDSポリフク リルアミドゲル電気泳動では，分子量27,000付近に浩染 した一本のハンドと淡染した数本のハンドが認められた (写真 1, 図 5 ). 


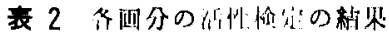

\begin{tabular}{|c|c|c|c|}
\hline 注入した讯料 & 汭: 人した漹料の量 & 洰人した部似。 & 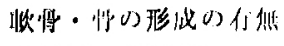 \\
\hline アテロコラーゲン & $2 \mathrm{ml}$ & 大腿激肪肉内多 & - \\
\hline Et-sup/フテロコラーダン & $15 \mathrm{mg} / 2 \mathrm{ml}$ & 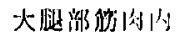 & - \\
\hline Et-ppt/生理食塩水 & $15 \mathrm{mg} / 2 \mathrm{~m} l$ & 大断部觔肉内 & + \\
\hline Et-ppt/フテロコラーゲン & $15 \mathrm{mg} / 2 \mathrm{ml}$ & 大煺部施约内 & + \\
\hline Et-ppt/フロコラーゲン & $15 \mathrm{mg} / 2 \mathrm{ml}$ & 颔项涑訬腅下 & + \\
\hline crown-Et-ppt/アテロコラーダン & $15 \mathrm{mg} / 2 \mathrm{ml}$ & 大瑯涪施约内 & + \\
\hline 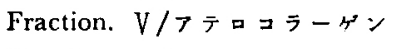 & $5 \mathrm{mg} / 1.5 \mathrm{ml}$ & 八湿部施肉内 & + \\
\hline Fraction. V/アテロコラーゲン & $0.5 \mathrm{mg} / 1.5 \mathrm{ml}$ & 大腿部斿肉内 & + \\
\hline
\end{tabular}

*フテロコラーゲンはすてて 0.50。醉性アテロコラーゲン溶液を用いている

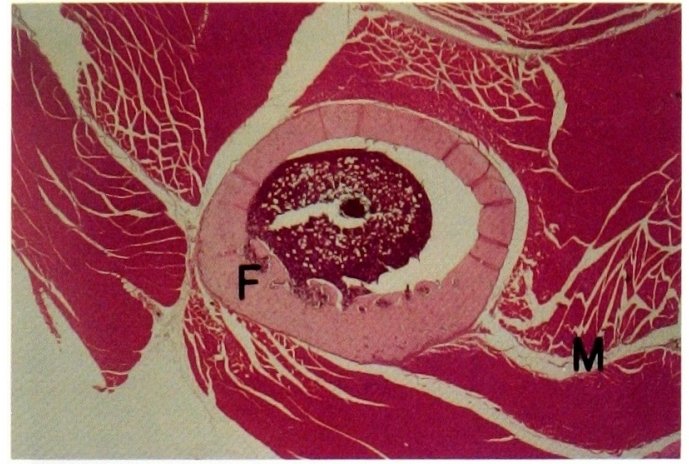

写真 2 アテロコラーゲン注入群 10 倍 H-E 染色

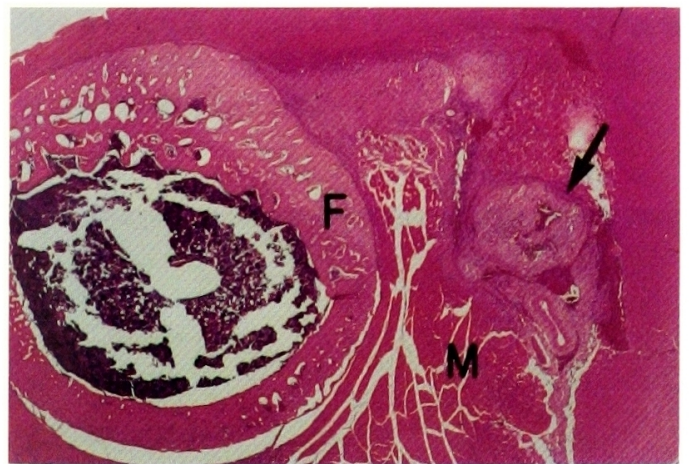

写真 3 Et-ppt/生理食塩水注入群 13倍 H-E染色

\section{2. 活性検定}

各画分の活性検定の結果は，表 2 に示した。 またその 組織所見は，以下の通りであった。

1) アテロコラーゲン単独注入群

2 週でほぼ完全にアテロコラーダンは吸収されてい て，正常な大脚部の組織像と同じであった（写直 2 ）.

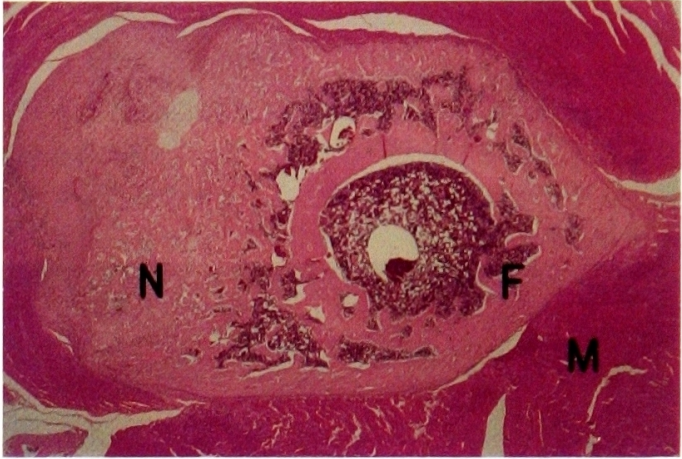

写真 4 Et-ppt/フテロコラーゲン注入群 10倍 $\mathrm{H}-\mathrm{E}$ 染色

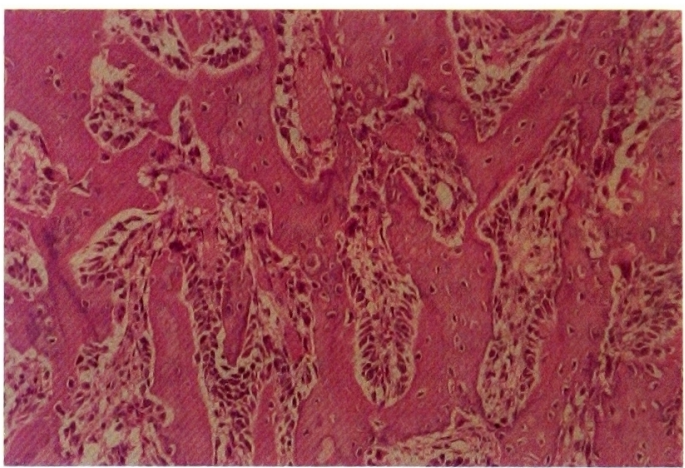

写真 5 Et-ppt/フテロコラーゲン注入群 100 倍 H-E 染色

2) Et-sup/フテロコラーゲン注入群

筋組織内に軽度の異物反応と線維芽細胞の增殖が認め られた

3) Et-ppt/生理食塩水注入群

筋組織内にわずかな軟骨・骨の形成が認められた（写 


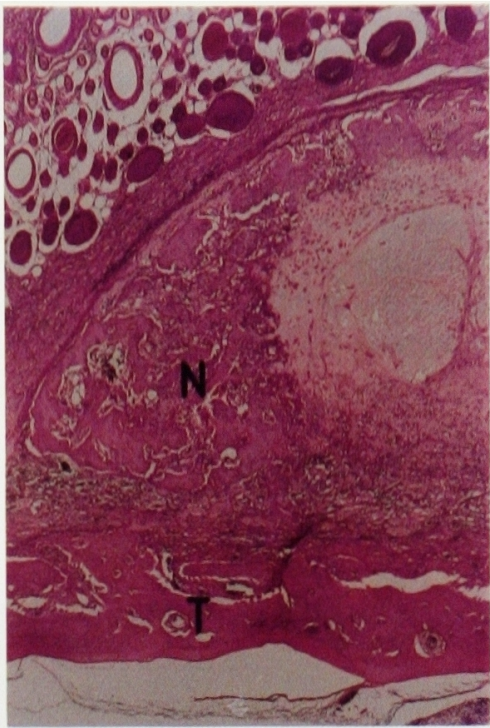

军亲 6 Et-ppt/フテロコラーゲン注 入群 28倍 H-E 染色

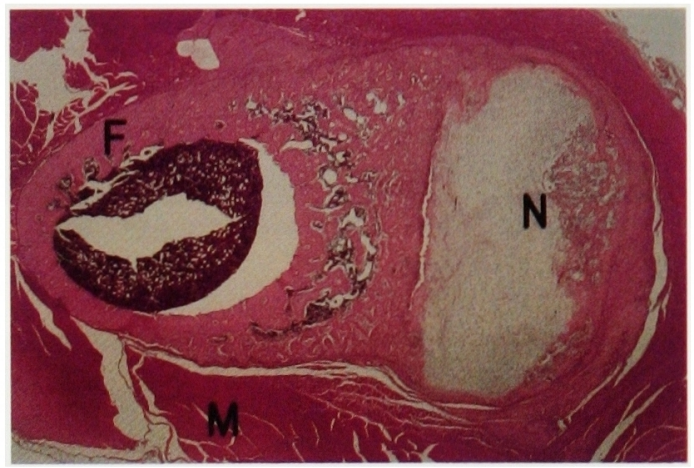

写真 7 p-Et-ppt (Fr. V $5 \mathrm{mg}) /$ フテロコラーダン 注入群 10 倍 H-E 染色

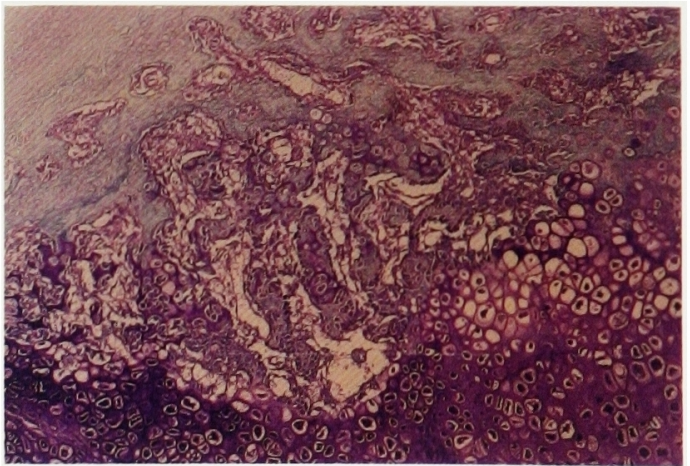

写真 8 p-Et-ppt (Fr. V 5 mg)/アテロコラーダン 注入群 50 倍 トルイシンブルー染色

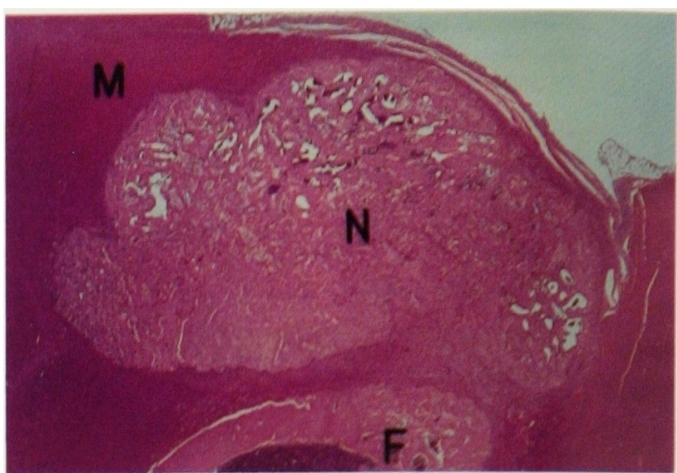

军正 9 p-Et-ppt (Fr. V 5 mg)/フチロコラーダン 注人群 10 位 月-上架色
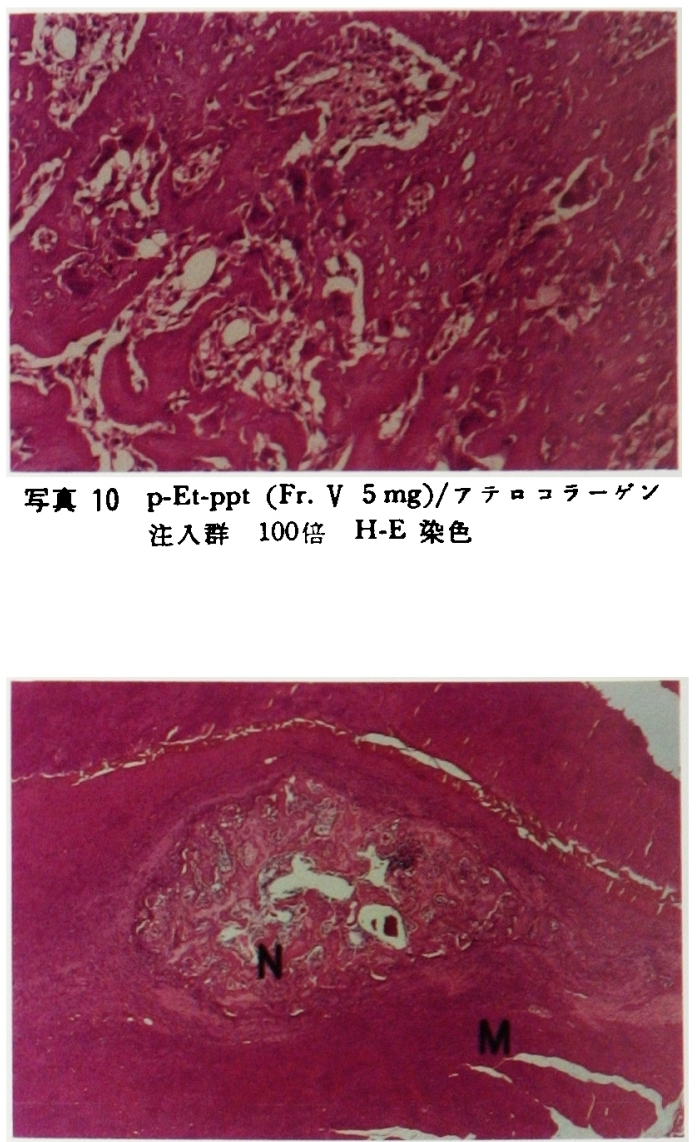

写真 11 p-Et-ppt (Fr. V $0.5 \mathrm{mg}) /$ フテコラーゲ ン过人群 26 倍 H-E 染色

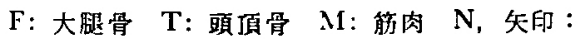
誘導された軟骨・骨 
(1).

4) Et-ppt/フテロコラーゲン注入群

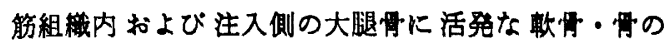
形成が認められ，誘導された骨の骨膜は大腿骨の骨膜之 連続していた（写而 4)，誘道された骨芽細胞は上皮細 胞様に配列し，細胞筫は好塩基性て活発に其基を形成 している像を呈していた（写可 5)，Et-ppt/フテロコラ

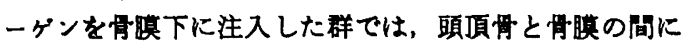
吸收されていない Et-ppt/フテロコラーゲンが存在し，

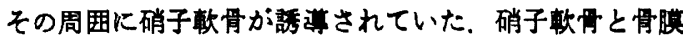
の間に骨形成が認められたが頭頂舴には特に变化は認め られなかった (写木 6).

5) crown-Et-ppt/フテロコラーダン注入群

Et-ppt/アテロコラーゲン注入群と全く同様の組織像 を示しており，Et-ppt と crown-Et-ppt との間には骨誘 導能の差は認められなかった。

6) p-Et-ppt/アテロコラーゲン注入群

p-Et-ppt（Fr. V) を $5 \mathrm{mg}$ 注入したラットでは，大腿 骨骨幹部に接して骨幹部の断面積よりも大きい硝子軟骨 が誘導されており（写索 7)，その周囲には軟骨内骨化 が認められた（写兵８），誘導された骨の骨膜は，大腿 骨の骨膜と連続していたか，反対側骨膜には特に変化は

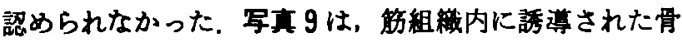
組織を示している，大腿骨に近い部分に一部軟骨が認め られたが大部分は骨噵様組織を伴った骨組織であった。 誘導された骨は多数の破骨細胞により吸収されており， 骨改造が盛んなことを示していた（写真 10). 同画分を $0.5 \mathrm{mg}$ 注入した場合, 筋組織内に軟骨・骨の誘導は認 められたものの $5 \mathrm{mg}$ 注入した場合に比べてその量は少 なかった (写真 11). Fr. V 以外の画分では, 筋組織内 に肉芽様の結合組織が認められるのみで, 軟骨・骨の形 成は全く認められなかった。

\section{考察}

\section{BMP の精靴}

BMP を精製するにあたって，BMP を可溶化するこ とが大きな研究課題とされていたが，高岡 ${ }^{15)}$ や花村 ${ }^{16)} ら$ によって 4 M塩酸クアニジンを用いた BMP の抽出法が 報告され，その精製に関する研究が進んだ．本実験にお いても $4 \mathrm{M}$ 塩酸クアニシンを用いて脱灰歯基質から BMP を抽出し，この抽出花に 3 倍量のエタノールを加 えることで BMP 画分を沈溊物 Et-ppt として回収し た．Et-sup には活性が羿められなかったことから, BMP はすべて Et-ppt として回収することができたと考えら れる。この方法は, 高岡ら ${ }^{8)}$ が Dunn 骨肉腫の BMP の精製に用いた方法であるが，骨肉腫では BMP 活性は 沈溉物ではなく，その上清にあった。また大山(7)，鴨 原 ${ }^{(8)}$ は，同方法を脱灰骨に用い，活性画分は骨肉腫同様
上淢にあることを根告している，

精製を通めた BMP (Fr，V)はエェタノールを加え て3時间経過しても少量の沈整物を生しただけであった か， 25,000以上の画分 (Fr. I 〜 V) ではニタノールを 加えるとただちに沈晸物が生した。したがってェタノー ル分画法て BMP 画分 Et-ppt として奻率よく回収て

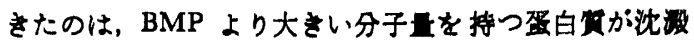
ナる過程で BMP が共沈したためではないかと部えられ ろ.

今回の实䀫に用いた Superose 12 は本来分析用であ

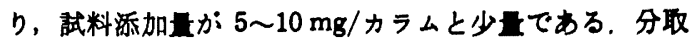
用には，Superose 12 と同じ分離バターンを得ることが できるとされる Superose 12 prep grade があるが, 十 分な分離度が得られなかったため，陚料の添加回数は多 くなるが Superose 12 を用いた。活性の琶められた Fr. Vを Superose 12 を用いて分析した結果, 分子量 13,700〜25,000の間にピークを持つ溶出ハターンが得ら れまた SDS ポリフクリルアミドゲル電気泳動では， 分子吾27,000付近にバンドが認められた。このことより 歯のBMP の分子共は，約 27,000 と推定されたが，この 值は米良らの報告》と一致している。しかし分倠は十分 とはいえずさらに精製を進め検討しなければならないと 考えられる。

\section{2. 象牙買由来の BMP}

Bang 5 $5^{19)}$ は，脱灰象牙質基質を眼中筋飞移植すると 骨が誘導されるか，象牙質形成前の脱灰した歯㗏を移植 しても骨誘導が認められないことから，象牙質の細胞成 分ではなく基質に骨を誘導する物質が存在しているので はないかと述べている，今回調整した脱灰崡冠部基質 は，象牙質のみでエナメル質やセメント質をはとんど含 んでいない.これから抽出した crown-Et-ppt に骨誘導 能が慧められたことから，象牙質に BMPが存在してい、 ることが直接証明されたと考えられる。精製に用いた脱 灰歯基質には象牙質の他にセメント質が含まれている。

しかし Et-ppt を Superose 12 で分析した結果, crownEt-ppt と全く同じ溶出ハターンが得られたので，セメン ト質の影響は汪とんどないるのと考え分離しないで精製 を進めた。

象牙質の BMP の分子量は，骨の BMP の分子量より 約 9,000大きいことから象牙質が形成される過程で周囲 の骨の BMP を取り込んたののではなく，象牙芽細胞が BMP を分泌している可能性があると考えられる。 しか し象牙質の BMP が生体内でどのよらな役割を果たして いるかについてはこれまで報告がなく現在のところ明ら かでない.

\section{BMP の担体としてのアテロコラーゲン}

精製したBMPを単独で移植しても周囲組織に払散し， 予想したほどの骨を誘導することが出来なかった ${ }^{5,10)}$. このことは BMP を局所に留めておくなんらかの担体が 
必要であることを示していると考えられる，また BMP

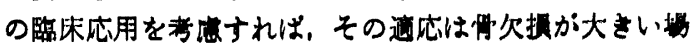
合であり，これを BMP 単独で神顷しよろとすると，大 且の BMP が必要となり，英用的ではない,日的。 Uriat $5^{10)}$ は, $\beta$-tricalcium phosphate との琵合移相夷题を行い, 中原ら尚は，ハイドロキシフパタトおよびフテロコラ ーダンなどの淈合移枚を試みている。

今回の实佮では BMP の担体の役剖を果たし，BMP を飭肉内に注入する材料として細胞培菜用に市肘されて

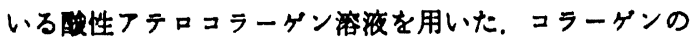
主な抗原決定部位は、コラーゲン分子の而端に位专ナる テロペブチドであることがかかっている、この部位は、

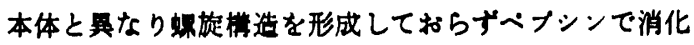
切断され，螺旋楼造の部分たけを取り出すことがで ろ ${ }^{20)}$.こ5して得られたフテロコラーゲンは，後述する コラーゲンの性筫を保ちながら抗原性は著しく低いた め, 生体材料としてはュラーゲンを用いるより有利であ る. Et-pptを生理食塩水あるいはフテロコラーゲンに混 合した場合，明らかに後者において活発な骨誘㫷が涀察 されたことから，アテロコラーゲンは担体として有奻に 機能していると考えられる.

Sampath ら 21$)$ は，同軼骨基害を4M 塩酸グアニシンンで 抽出した残榅と BMP を再權成し移植すると, 骨誘学能 が回復し，一方骨と同じI型コラーゲンである腱と

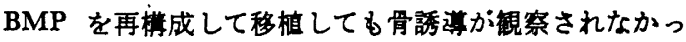
たことから，骨基筫の立体構造が細胞の基質体存の增殖 や分化に適した環境を作り出していると述べている. 本 実験で用いたアテロュラーゲンは，真皮から調整してお り，また立体構造もコラーゲンとは異なるか， BMP 画 分との混合により活発な骨誘前が認められ，必ずしる骨 基質を用いなくてる BMP の活性を协率よく発現するこ とができると考えられる，またコラーゲンは，細胞を 呼び込む作用があり，細胞增殖の足場として传れてお り, in vitro の実験では細胞の分化にす関係しているとさ れている.このよらにコラーゲンには, 細胞との相互作 用といら他の合成材料にはみられない性貿がある 22 24). 本実験においてる BMP の保持や徐放の他にす，このよ らな性質が骨誘導においてなんらかの役割を果たしてい るのではないかと推察され，骨誘導を効率よく発現する という点では他の生体材料より供れていると考えられ る.なお in vitro では, 酸性アテロコラーゲン容液は $37^{\circ} \mathrm{C}$ に加温すると変性し螺旋檴造がほどけてしまいせ ラチン化する. 一方酸性アテロコラーゲンを $\mathrm{pH}$ やイ オン強度を生理的条件下に調節して $37^{\circ} \mathrm{C} に$ 加温すると 織維を形成してゲル化するとされている23,24). 生体内 に注入された酸性アテロコラーゲンがどのような構造を とっているかについては明らかでない。

4. BMP の骨組蓝に対する作用

従来 BMP の活性恰定は，異所性骨形成によって行わ
れてきたか，本来 BMP は解存在し骮に作用与る因子 である，需欠损を作り，BMP を秘植すると速やかに骨の

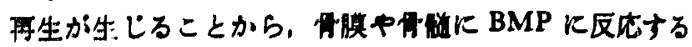

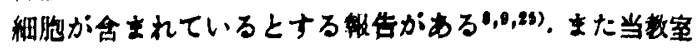

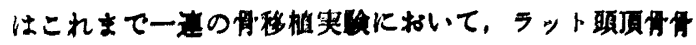

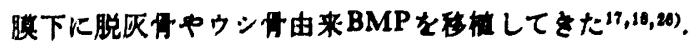

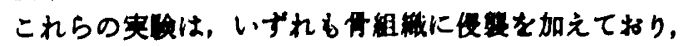
またハイドロキシフハタイトのよろな BMP 活性を有し

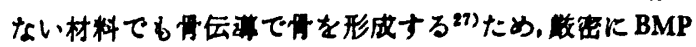

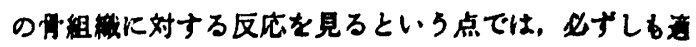

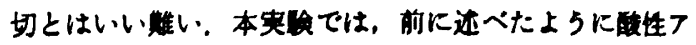

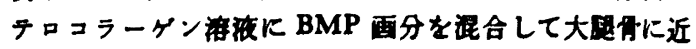

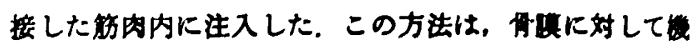
械的障客を与えることが少なく，また非鼬血的であるた め感架の可能性る少なく，確实に注入すれは目的とする

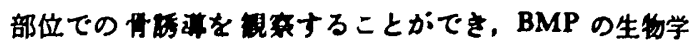
的性買を四へる方法として倛れていると考えられる。

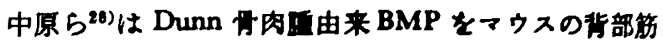

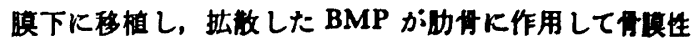

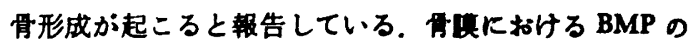

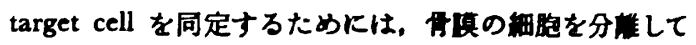
各細胞群に BMP を作用させて活性菼定を行わなければ

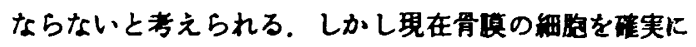
分離することは困䧽であり，BMP の target cell 柱 飞in vivo の実猃結果より推察されているる,9).

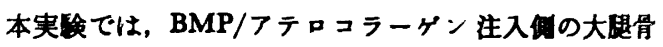

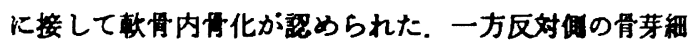
胞は，単首扁平細胞様に巨列しており，休止期の不活発な 骨芽細胞であった。本来長管骨骨幹の径の成長は，骨謨

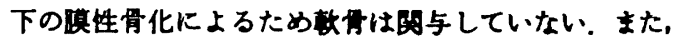
頭頂骨骨膜下に Et-ppt/フテロコラーダンを注入した群

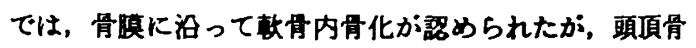
にははとんど反応が謏められなかった。 以上のことか

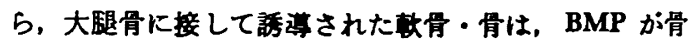
膜に直接作用して話導されたるのと考えられ，骨倬に齿 由来 BMP の target cell が存在していると推察された. しかし今回の実検ではこの練胞を同定することはできな かった，骨獏に生じた静内骨化は，骨折において仮骨 の中の軟骨が软骨内骨化で骨になる過程と類似してお り，骨折の治寉に BMP が成与している可能性を示唆す る.このよらに骨瞙は滇内骨化により骨を形成すると同 時に，軗骨内骨化で骨を形成する能力る有している．乙 かし骨折以外で骨獏の教骨内骨化がどの上らな役割を果 たしているかは，骨䠑における未分化間葉系細胞から骨 芽細胞にいたる分化の過程とあわせて今後の研究課題で ある. 


\section{結}

1. ウシ脱灰贯基筫の $4 \mathrm{M}$ 塩酸グフニジン抽出画分に エタノールを加えることで BMP 画分を析出させること ができ，ウシ象牙質に BMP 活性があることが証明され た.

2. ウシ脱灰齿の BMP を部分精製した 絬果，分子童 約27,000の蛋白筫であった。

3. BMP の作用で骨膜に軟骨内骨化が生した。このこ とから骨膜に BMP の target cell が存在していることが 推察された。

4. フテロコラーゲンは BMP の活性を奻率よく発現 させ，担体として有用であると考えられた。

本論文の一部は，第41回日本口腔科学会総会 (1987年 4 月 東京)、第 32 回日本口腔外科学会総会 (1987年11 月東京) に拉いて哞表した。

稿を䅂えるにあたり，䅂始概第なるこ指遵とこ校閲を 賜った手島貞一教授に深甚なる感謝の意を表します。

併せて，論文校閲の労をとられた本学口腔解剖学第二 講座加賀山学教授に深謝するとともに，本研究の推進に 際して，こ助言，こ協力をいただいた越後成志先生，幸 地省子先生, 山口泰先生, 松田耕策先生, 安藤良晴先 生, 鴫原隆先生,ならびに教室員の諸兄に深く感謝の意 を表します。

\section{引用 文 献}

1) Seyedin, S.M., Thomas, T.C., et al.: Purification and characterization of two cartilageinducing factors from bovine demineralized bone. Proc. Natl. Acad. Sci. USA 82: 226722711985.

2) Farley, J.R. and Baylink, D.J.: Purification of a skeletal growth factor from human bone. Biochemistry 21: 3502-3507 1982.

3) Kato, Y., Nomura, Y., et al.: Cartilage-derived factor (CDF) I. Stimulation of proteoglycan synthesis in rat and rabbit costal chondrocytes in culture. Exp Cell Res 130: 73-81 1980.

4) Urist, M.R. and Strates, B.S.: Bone morphogenetic protein. J Dent Res 50: 1392-1406 1971.

5) Urist, M.R., Huo, Y.K., et al.: Purification of bovine bone morphogenetic protein by hydroxyapatite chromatography. Proc. Natl. Acad. Sci. USA 81: 371-375 1984.

6) Takaoka, K., Yoshikawa, H., et al.: Purification of a bone-inducing substance (osteogenic factor) from a murine osteosarcoma. Biomed Res 2: 466-471 1981.

7）米良和彦，水谷英樹，他：骨形成因子に関する

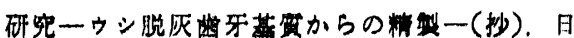
口科洁 36: 10981987.

8) Sato, K. and Urist, M.R.: Induced regeneration of calvaria by bone morphogenetic protein (BMP) in dogs. Clin. Orthop. 197: 301-311 1985.

9) Nilsson, O.S., Urist, M.R., et al.: Bone repair induced by bone morphogenetic protein in ulnar defects in dogs. J Bone Joint Surg 68B: 635-642 1986 .

10) Urist, M.R., Lietze, A., et al.: $\beta$-tricalcium phosphate delivery system for bone morphogenetic protein. Clin. Orthop. 187: 277-280 1984.

11）中原治应，高岡邦夫：骨形成因子の臨床応用の 可能性。形成外科 6：535-542 1987 .

12) Conover, M.A. and Urist, M.R.: Transmembrane bone morphogenesis by implants of dentine matrix. J Dent Res 58: 19111979.

13) Laemmli, U.K.: Cleavage of structural proteins during the assembly of the head of bacteriophage. T 4 . Nature 227: 680-685 1970.

14) Plank, J. und Rychlo, A.: Eine Schnellentkalkungsmethode. Zentralbl. f. Path. Anat. 89: 252-254 1952.

15) Takaoka, K., Ono, K. et al.: Solubilization and concentration of a bone-inducing substance from a murine osteosarcoma. Clin. Orthop. 148: 274-280 1980.

16) Hanamura, H., Higuchi, Y., et al.: Solubilized bone morphogenetic protein (BMP) from mouse osteosarcoma and rat demineralized bone matrix. Clin. Orthop. 148: 281-290 1980.

17）大山 治：牛脱灰骨由来骨形成因子に関する実 駼的研究, 東北大掬誌 4: 123-134 1985.

18）鴫原隆：牛骨由来骨形成因子に関する実監的 研究。東北大米誌 5: 75-86 1986 。

19) Bang, G. and Urist, M.R.: Bone induction in excavation chambers in matrix of decalcified dentine. Arch Surg 94: 781-789 1967.

20）永井 裕, 藤本大三郎, 他：コラーゲン代謝と 疾患。第 1 版, 讙談社, 東京, 1982, 134-154 頁.

21) Sampath, T.K. and Reddi, A.H.: Dissociative extraction and reconstitution of extracellular matrix components involved in local bone differentiation. Proc. Natl. Acad. Sci. USA 78: 7599-7603 1981.

22）宮田睓夫：コラーゲンと血小板の相互作用. 化 学の項域增刊 135: 31-41 1982.

23）宮田睴夫：パイオテクノロジーへの織維材料の 応用. 擮䊒と工業 39：427-435 1983.

24）宮田喗夫：バイオマテリフルとしてのコラーゲ 
ン膜. 膜 10：268-278 1985 .

25) Takagi, K. and Urist, M.R.: The role of bone marrow in bone morphogenetic proteininduced repair of femoral massive diaphyseal defect. Clin. Orthop. 171: 224-231 1982.

26）安藤良晴：脱灰骨の Onlay Graft に関する実
験的研究. 東北大歯誌 1:91-104 1983.

27）高木幸人：合成ハイドロキシアパタイトの骨膜 下 Only Graft に関する基礎的研究. 東北大歯 誌 4: 135-151 1985.

28）中原治彦, 津田隆之, 他：骨形成因子の骨膜に 対する作用 (抄). 日骨代謝誌 5：70 1987 . 